\title{
Assessment of Relationship Between Nutritional Status and Handgrip Strength in Hemodialysis Patients
}

\author{
Sevil Karahan Yılmaz ${ }^{1}$, Neslişah Rakıcıoğlu²*
}

\begin{abstract}
In hemodialysis patients, the prevalence of malnutrition is high; a decrease in muscle strength is observed.

The objective of the research was to evaluate the nutritional status of hemodialysis patients and the relationship between the nutritional status and muscle strength.

Materials and Methods. Sixty hemodialysis patients (38 males, 22 females) were chosen from among volunteers. Food consumption, biochemical values, anthropometric measurements, body composition, physical activity status, subjective global assessment, and handgrip strength in individuals were examined.

Results. According to subjective global assessment, $73.3 \%$ of patients were well-nourished, $26.7 \%$ of patients were moderately malnourished. In male patients, a moderate positive correlation was determined between handgrip strength and lean body mass $(r=0.359, p<0.05)$, albumin level $(r=0.408, p<0.05)$, energy intake $(r=0.437, p<0.05)$, protein intake $(r=0.345, p<0.05)$. In female patients, a moderate positive correlation was determined between handgrip strength and body weight $(r=0.470, p<0.05)$, body mass index $(r=0.472, p<0.05)$, triceps skinfold thickness $(r=0.530, p<0.05)$, mid-upper arm circumference $(r=0.515, p<0.05)$, mid-upper arm muscle circumference $(r=0.557, p<0.05)$, lean body mass $(r=0.470, p<0.05)$, body fat content $(\%)(r=0.588$, $p<0.05)$, albumin level $(r=0.565, p<0.05)$.

Conclusions. Handgrip strength alongside with more than one method of food consumption, biochemical parameters, subjective global assessment, anthropometric measurements, and body composition should be used for assessing the nutritional status in hemodialysis patients.
\end{abstract}

\section{Keywords}

hemodialysis, nutritional status, anthropometric measurements, biochemical parameters, muscle strength

${ }^{1}$ Erzincan Binali Yildirim University, Erzincan, Turkey

${ }^{2}$ Hacettepe University, Ankara, Turkey

*Corresponding author: neslisah@hacettepe.edu.tr

Copyright @Neslişah Rakıcıoğlu, Sevil Karahan Yılmaz, 2020

\section{Problem statement and analysis of the latest research}

End-stage renal disease (ESRD) is a major public health problem due to increasing the incidence in the world and in our country, causing high morbidity and mortality rates, severely influencing quality of life, and high-cost need for renal replacement therapy and poor prognostic course [1]. Technolog- ical and surgical advances have facilitated the treatment of hemodialysis (HD) [2]. However, during the treatment of $\mathrm{HD}$, complications may develop. Metabolic disorders, protein-energy malnutrition (PEM), infection, cardiovascular diseases, uremic complications, non-uremic complications, and malnutrition are observed [3]. The loss of muscle protein storage, decrease in muscle strength, and lack of physical activity are observed in malnutrition [4]. 
Handgrip strength (HGS) is a direct marker of body muscle mass. In HD patients, grip strength is used as a marker of the nutritional status. Low HGS was associated with inadequate nutrition [5].

The objective of the research was to assess malnutrition in HD patients, determine the nutritional status, and analyze the relationship between the nutritional status and anthropometric measurements, body composition, some blood parameters, and HGS.

\section{Materials and Methods}

Sixty volunteer HD patients (38 males, 22 females) at the age of 18-65 years, undergoing HD for more than 6 months were included in the study. A poll was taken to patients to collect the data about general information, nutrition habits, and physical activity status. Height, mid-upper arm circumference (MUAC), and triceps skinfold thickness (TSF) of patients were measured. Bodyweight measurements were taken after HD. The patients' body mass index (BMI) was calculated divided by the square of height and mid-upper arm muscle circumference (MUAMC) was calculated using equation "MUAMC $=$ MUAC $-(\pi \times$ TSF $)$ " [6]. Body fat mass, lean body mass (muscle mass), body water content, basal metabolic rate (BMR), and body fat content, were measured by bioelectrical impedance analysis (BIA) after hemodialysis.

HGS in the individuals who participated in the study was measured by using the JAMAR hydraulic hand dynamometer [7]. HGS was evaluated in both arms after HD sessions. HGS was repeated three times and the highest value was used in the analysis. Biochemical analysis of routinely collected blood samples was performed in the Biochemistry Laboratory of Erzincan State Hospital. The blood values for routine follow-up in HD patients were examined from the patient's file. Subjective global assessment (SGA) was applied as described by Detsky et al. [8].

Individual food consumption records were taken from patients within three consecutive days including one dialysis treatment day, a week day, and a weekend day [9]. The data from dietary recall forms were analyzed by a computer program the Nutrition
Information System (BeBiS) [10]. The calculated values were compared with the values of recommended daily intake of dialysis patients; the levels of competence have been identified [11]. Twentyfour-hour physical activity record forms filled out during three days of food consumption were taken. Total energy expenditure was calculated by multiplying the time spent on activities by the minute to minute resting metabolic rate (RMR), and the physical activity ratio (PAR) values. The patients' physical activity level is total energy expenditure divided by basal metabolic rate value $(\mathrm{PAL}=$ total energy/BMR) [6].

\section{Statistical Analyses}

The data obtained from the study were evaluated using SPSS 21 software. There were used descriptive statistics according to data characteristics, the median values, and, at least, most of the range. The median and minimum-maximum values given did not show normal distribution; the Mann-Whitney $U$ test and the Kruskal-Wallis tests were used. Pearson's correlation analysis was applied for examining the relationship between the values in the tables. For the analyses, $\mathrm{p}$ values less than 0.05 were considered significant [12].

Clinical Research Ethics Board of the Hacettepe University Faculty of Medicine approved this study. The informed consent was obtained from the patients before the study.

\section{Results}

Sixty HD patients participated in the study $-63.3 \%$ of males and $36.7 \%$ of females. The average age of male patients $(n=38)$ was $51.3 \pm 12.7$ years and the average age of female patients $(n=22)$ was $48.5 \pm 13.3$ years. The duration of undergoing HD was $52.9 \pm 41.6$ months in males and $43.9 \pm 41.9$ months in females.

The patient's classification according to SGA is shown in Table 1. According to SGA, 73.3\% of patients were well-nourished.

The patients' average HGS according to some parameters was given. In male patients, there were statistically significant differences between choles- 
Table 1. Distribution of patients according to the SGA.

\begin{tabular}{lcccccc}
\hline \multirow{2}{*}{ SGA Classification } & \multicolumn{2}{c}{$\begin{array}{c}\text { Males } \\
(\mathrm{n}=38)\end{array}$} & \multicolumn{2}{c}{$\begin{array}{c}\text { Females } \\
(\mathrm{n}=22)\end{array}$} & \multicolumn{2}{c}{$\begin{array}{c}\text { Total } \\
(\mathrm{n}=60)\end{array}$} \\
\cline { 2 - 7 } & $\mathrm{n}$ & $\%$ & $\mathrm{n}$ & $\%$ & $\mathrm{n}$ & $\%$ \\
\cline { 2 - 7 } A (well-nourished) & 31 & 81.6 & 13 & 59.1 & 44 & 73.3 \\
B (moderately malnourished) & 7 & 18.4 & 9 & 40.9 & 16 & 26.7 \\
C (severely malnourished) & - & - & - & - & - & - \\
Total & 38 & 100.0 & 22 & 100.0 & 60 & 100.0 \\
\hline
\end{tabular}

terol levels and SGA regarding HGS $(\mathrm{p}<0.05)$. In female patients, a statistically significant difference was observed between HGS and albumin, blood urea nitrogen (BUN) levels, BMI classification, and protein consumption $(\mathrm{g} / \mathrm{kg})(\mathrm{p}<0.05)$ (Table 2$)$.

In male patients, a statistically significant moderate correlation was found between HGS and lean body mass, albumin level, energy intake and protein consumption; a negative power correlation was found between HGS and SGA $(p<0.05)$. In female patients, a statistically significant positive moderate correlation was found between HGS and body weight, BMI, TSF, MUAC, MUAMC, lean body mass, fat percentage, and albumin $(p<0.05)$ (Table 3).

\section{Discussion}

In this study, we conducted the assessment of the relationship between the nutritional status and muscle strength in patients undergoing $\mathrm{HD}$; according to SGA, $73.3 \%$ of patients were well-nourished and $26.7 \%$ of patients were moderately malnourished. According to Kirushnan et al., among 93 HD patients who participated in the study, $68 \%$ of patients were well-nourished and $32 \%$ of patients were undernourished (there were $29 \%$ of moderate and 3\% of severe malnutrition cases) [13]. Koor $e t$ al. found that in a study that included 190 HD patients, according to SGA, $8.4 \%$ of patients were well-nourished, $47.4 \%$ of patients were mildly malnourished and $44.2 \%$ of patients were moderately malnourished [14]. In another study that comprised $73 \mathrm{HD}$ patients, mild, moderate, and severe PEM were observed in $51.4 \%, 45.9 \%$, and $1.4 \%$ of cases, respectively [15]. According to this study, the prevalence of malnutrition determined in our country was relatively lower than in other studies. A dialysis center was private and the presence of a dietitian in a public hospital was considered to be effective for these results. SGA determines the degree of malnutrition; however, it does not include anthropometric measurements and biochemical parameters. Therefore, especially in patients with renal failure, in the determination of the nutritional status, such data have to be evaluated.

PEM is common in patients with chronic renal failure and has been reported to be associated with increased morbidity and mortality [16]. According to the International Society of Renal Nutrition and Metabolism (ISNRM), if there was a decrease in albumin, transferrin and cholesterol levels, reduction in body weight and muscle mass (muscle loss or MUAC reduction), PEM can be diagnosed [16, 17]. Muscle mass or muscle loss is diagnosed using functional tests of HGS $[18,19]$. The reference values are healthy individual data; there has not been observed a study classifying muscle loss according to HGS in patients undergoing HD. However, the effect of muscle strength on dialysis variables was evaluated in several studies. In the study involving $43 \mathrm{HD}$ patients, HGS measured after HD in male patients was $30.9 \pm 9.9 \mathrm{~kg}$ and in female patients, it was $14.5 \pm 6.3 \mathrm{~kg}$ [20]. In another study, among $156 \mathrm{HD}$ patients, HGS in male patients was $32.6 \pm 8.4 \mathrm{~kg}$ and in female patients, it was $21.0 \pm 6.9 \mathrm{~kg}$ [21]. In the study conducted in $34 \mathrm{HD}$ patients, HGS measured in males and females were $21.9 \pm 8.8$ and $17.3 \pm 5.3 \mathrm{~kg}$, respectively [22]. Vogt et al. found that in $265 \mathrm{HD}$ patients, HGS value in men was $24.0 \pm 11.4 \mathrm{~kg}$ 
Table 2. Handgrip strength of patients according to some parameters.

\begin{tabular}{|c|c|c|c|c|c|c|c|c|}
\hline & \multicolumn{8}{|c|}{ Handgrip Strength $(\mathrm{kg})$} \\
\hline & \multicolumn{4}{|c|}{ Males $(n=38)$} & \multicolumn{4}{|c|}{ Females $(n=22)$} \\
\hline & Median & Min & Max & $\mathrm{p}_{1}$ & Median & Min & Max & $\mathrm{p}_{2}$ \\
\hline Sex & 24.6 & 8.2 & 42.6 & - & 11.6 & 5.4 & 22.8 & - \\
\hline \multicolumn{9}{|c|}{ Duration of Dialysis (years) } \\
\hline$<5$ & 19.9 & 12.3 & 42.6 & \multirow{2}{*}{0.767} & 10.9 & 8.7 & 22.8 & \multirow{2}{*}{0.507} \\
\hline$\geq 5$ & 18.8 & 8.2 & 34.6 & & 13.0 & 5.4 & 17.8 & \\
\hline \multicolumn{9}{|c|}{ SGA Assessment } \\
\hline $\mathrm{A}$ & 21.7 & 12.3 & 42.6 & \multirow{2}{*}{$0.010 *$} & 13.4 & 8.7 & 22.8 & \multirow{2}{*}{0.095} \\
\hline $\mathrm{B}$ & 9.7 & 8.2 & 34 & & 8.7 & 5.4 & 15.8 & \\
\hline \multicolumn{9}{|c|}{ BMI $\left(\mathrm{kg} / \mathrm{m}^{2}\right)^{* * *}$} \\
\hline$<18.5$ & - & - & - & \multirow{4}{*}{0.219} & 6.0 & 5.4 & 11.2 & \multirow{4}{*}{$0.042 * *$} \\
\hline $18.5-24.9$ & 18.2 & 8.2 & 42.6 & & 7.7 & 6.2 & 13.7 & \\
\hline $25-29.9$ & 19.6 & 8.6 & 39.8 & & 13.1 & 9.2 & 17.7 & \\
\hline$>30$ & 32.5 & 33.2 & 34.3 & & 13.8 & 9 & 22.8 & \\
\hline \multicolumn{9}{|c|}{ BUN (mg/dL) } \\
\hline$<50$ & 16.6 & 8.2 & 34.6 & \multirow{2}{*}{0.220} & 9.7 & 5.4 & 22.8 & \multirow{2}{*}{$0.021 *$} \\
\hline$\geq 50$ & 21.1 & 12.3 & 42.6 & & 17.4 & 15.1 & 17.7 & \\
\hline \multicolumn{9}{|c|}{ Total Cholesterol (mg/dL) } \\
\hline$<200$ & 18.1 & 8.2 & 38.7 & \multirow{2}{*}{$0.010 *$} & 12.9 & 8.7 & 22.8 & \multirow{2}{*}{0.216} \\
\hline$\geq 200$ & 35.3 & 33.2 & 42.6 & & 9.4 & 5.4 & 17.7 & \\
\hline \multicolumn{9}{|c|}{ Total Protein (g/dL) } \\
\hline$<6.5$ & 17.5 & 8.6 & 34.3 & \multirow{2}{*}{0.536} & 10.9 & 10 & 10.3 & \multirow{2}{*}{0.480} \\
\hline$\geq 6.5$ & 20.1 & 8.2 & 42.6 & & 13.3 & 5.4 & 17.7 & \\
\hline \multicolumn{9}{|c|}{ Albumin (g/dL) } \\
\hline$<3.5$ & 14.3 & 8.6 & 38.7 & \multirow{2}{*}{0.088} & 6.0 & 5.4 & 16.2 & \multirow{2}{*}{$0.017 *$} \\
\hline$\geq 3.5$ & 21.4 & 8.2 & 42.6 & & 13.5 & 10 & 22.8 & \\
\hline \multicolumn{9}{|c|}{ Hemoglobin (g/dL) } \\
\hline$<10$ & 19.0 & 13 & 42.6 & \multirow{2}{*}{0.603} & 11.2 & 9 & 15.8 & \multirow{2}{*}{0.867} \\
\hline$\geq 10$ & 21.6 & 8.2 & 39.8 & & 11.6 & 5.4 & 22.8 & \\
\hline Energy In & ke (kcal/ & & & & & & & \\
\hline$<35$ & 18.6 & 8.2 & 42.6 & 0.254 & 11.4 & 8.7 & 22.8 & 0117 \\
\hline$\geq 35$ & 35 & 35 & 35 & & 8.5 & 5.4 & 12.1 & 0.117 \\
\hline Protein In & ke (g/kg) & & & & & & & \\
\hline$<1.2$ & 20.3 & 8.2 & 39.8 & 0454 & 12.0 & 9 & 22.8 & 0011* \\
\hline$\geq 1.2$ & 21.6 & 8.6 & 42.6 & 0.454 & 8.9 & 5.4 & 15.1 & 0.011 \\
\hline
\end{tabular}

Notes: * - significance from basal values; $\mathrm{p}<0.05$ Mann-Whitney $\mathrm{U}$ test, $\mathrm{p}_{1}=$ males; $\mathrm{p}_{2}=$ females; ** - Kruskal-Wallis test.

and in women, it was $12.5 \pm 6.5 \mathrm{~kg}$ [23]. In this study, HGS in male and female patients were 24.6 (8.2-42.8) $\mathrm{kg}$ to $11.6(5.4-22.8) \mathrm{kg}$, respectively (Table 2). Schlüssel et al. reached the reference value of HGS by studying healthy individuals and different ethnic groups [19]. Leal et al. reached HGS values by studying different ethnic groups of HD patients [20]. While assessing loss of mus- 
Table 3. Correlation (r) between handgrip strength and some parameters.

\begin{tabular}{|c|c|c|c|c|}
\hline & \multicolumn{4}{|c|}{ Handgrip Strength } \\
\hline & \multicolumn{2}{|c|}{ Males $(n=38)$} & \multicolumn{2}{|c|}{ Females $(n=22)$} \\
\hline & $\mathrm{r}$ & $\mathrm{p}$-value & $\mathrm{r}$ & p-value \\
\hline Age & -0.250 & 0.129 & 0.124 & 0.582 \\
\hline Height & 0.096 & 0.566 & 0.120 & 0.594 \\
\hline Body weight & 0.265 & 0.108 & 0.470 & $0.027 *$ \\
\hline BMI & 0.256 & 0.121 & 0.472 & $0.026 *$ \\
\hline TSF & 0.219 & 0.187 & 0.530 & $0.011 *$ \\
\hline MUAC & 0.202 & 0.224 & 0.515 & $0.014 *$ \\
\hline MUAMC & 0.082 & 0.625 & 0.557 & $0.007 *$ \\
\hline LBM & 0.359 & $0.027 *$ & 0.470 & $0.027 *$ \\
\hline Fat Percentage $(\%)$ & -0.029 & 0.861 & 0.588 & $0.004 *$ \\
\hline ALP & 0.054 & 0.746 & -0.463 & $\mathbf{0 . 0 3 0} *$ \\
\hline Total Cholesterol & 0.281 & 0.088 & -0.204 & 0.363 \\
\hline Total Protein & 0.033 & 0.845 & -0.305 & 0.168 \\
\hline Albumin & 0.408 & 0.011* & 0.565 & $0.006 *$ \\
\hline Calcium & -0.155 & 0.354 & -0.214 & 0.338 \\
\hline PTH & -0.140 & 0.401 & -0.351 & 0.109 \\
\hline SGA & -0.424 & $0.008 *$ & -0.365 & 0.095 \\
\hline Duration of Dialysis & -0.047 & 0.779 & 0.043 & 0.848 \\
\hline Energy Intake & 0.437 & $0.006 *$ & -0.042 & 0.853 \\
\hline Protein Consumption & 0.345 & $0.034 *$ & -0.135 & 0.549 \\
\hline
\end{tabular}

Note: $*$ - significance from basal values $\mathrm{p}<0.05$.

cle, Schlüssel et al. [19] and Leal et al. [20] have presented a cut-off point $\left(10^{\text {th }}\right.$ percentile). According to Schlüssel et al. [19] and Leal et al. [20], these values $\left(<10^{\text {th }}\right.$ percentile $)$ were on average as follows: for males and females at the age of 20-29 years -33.95 and $19.05 \mathrm{~kg}$; for males and females at the age of $30-39$ years -35.65 and 20.04 $\mathrm{kg}$; for males and females at the age of 40-49 years -33.35 and $19.01 \mathrm{~kg}$; for males and females at the age of 50-59 years -29.90 and $16 \mathrm{~kg}$; and for males and females at the age of 60-69 years -26.45 and $15.8 \mathrm{~kg}$. However, malnutrition or good nutrition defines a cut-off point that has not been established. In some studies of HD patients, HGS was reported to be lower in malnourished patients [24]. The study involving $330 \mathrm{HD}$ patients, while assessing low muscle strength, has presented the cut-off point of $<30 \mathrm{~kg}$ in men and $<20 \mathrm{~kg}$ in women. Low muscle strength was found in $36 \%$ of patients. Low muscle strength was seen in $76 \%$ of patients with PEM [25]. In this study, $18.4 \%$ of males, $40.9 \%$ of females, and $26.7 \%$ of all patients undergoing HD were found to be diagnosed with PEM. PEM indicates the presence of muscle loss. In this study, in well-nourished and malnourished male patients, HGS was 21.7 (12.3-42.6) $\mathrm{kg}$ and $9.7(8.2-34) \mathrm{kg}$, respectively, while in well-nourished and malnourished female patients, HGS was $13.4(8.7-22.8) \mathrm{kg}$ and $8.7(5.4-15.8) \mathrm{kg}$, respectively. Malnourished patients with decreased muscle strength are the case of loss of muscle protein stores.

Dietary energy intake of about $30-35 \mathrm{kcal} / \mathrm{kg} / \mathrm{d}$ and protein intake of about $1.2 \mathrm{~g} / \mathrm{kg} / \mathrm{d}$ is recommended for HD patients [26]. In this study, the recommended daily average protein intake was $1.2 \pm 0.3 \mathrm{~g} / \mathrm{kg}$. The recommended daily average energy intake was $26.3 \pm 6.6 \mathrm{kcal} / \mathrm{kg} / \mathrm{d}$. Consuming the recommended protein levels is important 
for HD patients for replacing amino acid loss that occurs during HD, lowering serum albumin and total protein levels and preventing PEM and negative nitrogen balance. There must be an appropriate dietary protein content per kilogram of the patient body; as the daily energy intake is low, the protein cannot be used for the purpose sufficiently and daily requirements have proved to be relatively more. Low energy and protein intake accompanied by catabolic results of dialysis therapy are known to lead to uremic malnutrition [27]. In addition, in HD patients, the decrease in muscle mass due to inadequate protein intake resulted from insufficient energy intake [28]. In this study, low values of grip strength were caused by inadequate protein intake due to insufficient energy intake that resulted from a decrease in muscle protein depot.

HGS is a simple indicator of skeletal muscle function and a functional indicator of the nutritional status [5]. HGS and MUAMC are suggested to be the best indicators of lean body mass [29]. According to the results of this study, in female patients, there was found a significant positive relationship between HGS and MUAC $(\mathrm{r}=0.515, \mathrm{p}<0.05)$ (Table 3).

The relationship between HGS and SGA were found in HD patients [22]. In this study, in male patients, there was found a negative relationship between SGA and HGS ( $r=-0.424, p<0.05)$. A negative relationship between HGS and SGA in male patients might be due to the high proportion of well-nourished male patients (81.6\%).

Considering the age, gender, and body weight, there is a a very strong relationship between hand force and lean body mass [30]. In this study, in both male and female patients, there was found a positive relationship between HGS and lean body mass $(r=0.359$ and $r=0.370, p<0.05)$. This result confirmed lean body mass to be a determinant of HGS.

\section{Conclusions}

According to the research results, when assessing the nutritional status in dialysis patients, it is important not to use a single method only; it is im- portant to use a combination of different methods of nutritional status assessment. To evaluate the nutritional status, the parameters such as food consumption, biochemical parameters (serum albumin, BUN, cholesterol), anthropometric measurements (bodyweight, height, MUAC, TSF), body composition analysis, and HGS should be used. In HD patients, the determination of HGS is a valid method for determining the nutritional status as its application is a quick, easy, cheap, and effective method.

\section{Prospects of Further Researches}

In our country, there are no adequate data on HGS in both HD patients and healthy individuals. Therefore, the study of HGS values and its relationship with nutrition for different age and gender groups is promising.

\section{Ethical Stnadarts}

Clinical Research Ethics Board of the Hacettepe University Faculty of Medicine approved this study.

\section{Informed Consent}

Informed consent was obtained from the patients before the study.

\section{Acknowledgements}

Thank you to all the patients that participated in this research.

\section{Conflict of Interest}

The authors stated no conflict of interest.

\section{Financial Disclosure}

The authors received no financial support for the research, authorship, and/or publication of this article.

\section{References}

[1] Runge SM, Greganti MA, Netter FH. Kronik bö brek yetmezliği. In: Netters internal 
medicine. Ankara: Gü neş Tıp Kitabevleri; 2009; 748-754.

[2] Sungur G, Tekinsoy P, Ceyhan Ö et al. Hemodiyaliz hastalarının evde bakım gereksinimleri. Nefroloji Hemşireliği Dergisi. 2010; 6 (1-2): 28-33.

[3] Eşit Ü M, Karadenizi G. Hemodiyaliz tedavisi gö ren hastaların yaşam kalitesi ve bilgilendirici hemşirelik yaklaşımının ö nemi. Fırat Sağlık Hizmetleri Dergisi. 2006; 1 (1): 33-43.

[4] Carrero JJ, Stenvinkel P, Cuppari L et al. Etiology of the protein-energy wasting syndrome in chronic kidney disease: A consensus statement from the International Society of Renal Nutrition and Metabolism (ISRNM). J Ren Nutr. 2013; 23 (2): 7790. DOI: https://doi.org/10.1053/ j.jrn.2013.01.001 [PMid:23428357]

[5] Leal V, Mafra D, Anjos D. Use of handgrip strength in the assessment of the muscle function of chronic disease patients on dialysis: A systematic review. Nephrology Dialysis Transplantation. 2011; 26 (4): 1354-1360. DOI: https://doi .org/10. $1093 / \mathrm{ndt} / \mathrm{gfq} 487$ [PMid:20709742]

[6] Pekcan G. Hastanın beslenme durumunun saptanması. In: Diyet El Kitabı Ankara: Hatipoğlu Yayınevi, 2013; 65-117.

[7] Hillman TE, Nunes QM, Hornby ST et al. A practical posture for handgrip dynamometry in the clinical setting. Clin Nutr. 2005; 24 (2): 224-228. DOI: https://doi. org/10.1016/j.clnu.2004.09.013 [PMid:15784482]

[8] Detsky AS, McLaughlin JR, Baker JP, et al. What is a subjective global assessment of nutritional status? JPEN J Parenter Enteral Nutr. 1987; 11 (1): 813. DOI: https://doi.org/10.1177/ 014860718701100108 [PMid:3820522]
[9] Lee RD, Nieman DC. Nutritional assessment. WM.C. Oxford: Brow Communications; c1993. 407p.

[10] Bebis (Beslenme Bilgi Sistemi). Nutrition Data Base Software. Database: The German Food Code and Nutrient Data Base (BLS II.3, 1999) with additions from USDA-sr and other sources. Istanbul. 2004.

[11] Zadeh K, Block G, Humphreys M et al. A low, rather than a high, total plasma homocysteine is an indicator of poor outcome in hemodialysis patients. J Am Soc Nephrol. 2004; 15 (2): 442 453. DOI: https://doi .org/10.1097/ $01 . A S N .0000107564 .60018 .51$

[PMid:14747392]

[12] Alpar R. Spor, sağlık ve eğitim bilimlerinden ö rneklerle uygulamalı istatistik ve geç erlikgü venirlik. Ankara: Nobel Yayınevi; c2016.

[13] Kirushnan BB, Rao BS, Annigeri R et al. Impact of Malnutrition, Inflammation, and Atherosclerosis on the Outcome in Hemodialysis Patients. Indian $\mathbf{J}$ Nephrol. 2017; 27 (4): 277-283. DOI: https : / / doi . org/10.4103/0971-4065.202830

[PMid:28761229 PMCid:PMC5514823]

[14] Koor BE, Nakhaie MR, Babaie S. Nutritional assessment and its correlation with anthropometric measurements in hemodialysis patients. Saudi J Kidney Dis Transpl. 2015; 26 (4): 697701. DOI: https://doi.org/10.4103/ 1319-2442.160146 [PMid:26178540]

[15] Pereire RA, Caetano AL, Cuppari L et al. Adductor pollicis muscle thickness as a predictor of handgrip strength in hemodialysis patients. J Bras Nefrol. 2013; 35 (3): 177184. DOI: https://doi .org/10.5935/ 0101-2800.20130029 [PMid:24100736]

[16] Kadiri M, Nechba R, Oualim Z. Factors predicting malnutrition in hemodialysis patients. Saudi J Kidney Dis Transpl. 2011; 22 (4): 695704. 
[17] Fouque D, Kalantar-Zadeh K, Kopple J et al. A proposed nomenclature and diagnostic criteria for protein-energy wasting in acute and chronic kidney disease. Kidney Int. 2008; 73 (4): 391398. DOI: https://doi.org/10.1038/ sj.ki. 5002585 [PMid:18094682]

[18] Norman K, Stobä us N, Gonzalez MC et al. Hand grip strength: outcome predictor and marker of nutritional status. Clin Nutr. 2011; 30 (2): 135-142. DOI: https : / / doi . org/10.1016/j.clnu.2010.09.010 [PMid:21035927]

[19] Schlü ssel MM, Anjos LA, Vasconcellos MTL et al. Reference values of handgrip dynamometry of healthy adults: A populationbased study. Clin Nutr. 2008; 27 (4): 601607. DOI: https : / /doi.org/10.1016/ j.clnu.2008.04.004 [PMid:18547686]

[20] Leal VO, Stockler-Pinto MB, Farage NE et al. Handgrip strength and its dialysis determinants in hemodialysis patients. Nutrition. 2011; 27 (11-12): 1125-1129. DOI: https://doi. org/10.1016/j.nut.2010.12.012 [PMid:21454052]

[21] Pinto AP, Ramos CI, Meireles MS et al. Impact of hemodialysis session on handgrip strength. J Bras Nefrol. 2015; 37 (4): 451457. DOI: https: / /doi.org/10.5935/ 0101-2800.20150072 [PMid:26648494]

[22] Morishita Y, Kubo K, Haga Y et al. Skeletal muscle loss is negatively associated with singlepool kt/v and dialysis duration in hemodialysis patients. Ther Apher Dial. 2014; 18 (6): 612617. DOI: https://doi.org/10.1111/ 1744-9987.12174 [PMid:24674153]

[23] Vogt BP, Borges MCC, Regina de Goes C et al. Handgrip strength is an independent predictor of all-cause mortality in maintenance dialysis patients. Clin Nutr. 2016; 35 (6): 1429-1433. DOI: https://doi.org/10.1016/j. clnu.2016.03.020 [PMid:27083497]
[24] Carrero JJ, Chmielewski M, Axelsson J et al. Muscle atrophy, inflammation, and clinical outcome in the incident and prevalent dialysis patients. Clin Nutr. 2008; 27 (4): 557 564. DOI: https://doi .org/10.1016/ j.clnu.2008.04.007 [PMid:18538898]

[25] Isoyama N, Qureshi HR, Avesani CA et al. Comparative associations of muscle mass and muscle strength with mortality in dialysis patients. Clin J Am Soc Nephrol. 2014; 9 (10): 1720-1728. DOI: https: //doi.org/10.2215/CJN.10261013 [PMid:25074839 PMCid:PMC4186520]

[26] National Kidney Foundation. Clinical practice guidelines for nutrition in chronic renal failure. Available from: https://www.kidney. org/professionals/guidelines

[27] İkizler TA. Protein and energy: recommended intake and nutrient supplementation in chronic dialysis patients. Semin Dial. 2004; 17 (6): 471-478. DOI: https://doi.org/10. 1111/j.0894-0959.2004.17608.x [PMid:15660578]

[28] Lorenzo V, Boris E, Rufino $\mathrm{M}$ et al. Caloric rather than protein deficiency predominates in stable chronic hemodialysis patients. Nephrol Dial Transplant. 1995; 10 (10): 1885-1889.

[29] Booth $\mathrm{M}$, Hunter $\mathrm{C}$, Gore $\mathrm{C}$ et al. The relationship between body mass index and waist circumference: implications for estimates of the population prevalence of overweight. Int J Obes Relat Metab Disord. 2000; 24 (8): 1058-1061. DOI: https:// doi.org/10.1038/sj.ijo.0801359 [PMid:10951546]

[30] Wang AY, Sea MM, Ho ZS et al. American society for clinical nutrition evaluation of handgrip strength as a nutritional marker and prognostic indicator in peritoneal dialysis patients. Am J Clin Nutr. 2005; 81 (1): 79 86. DOI: https://doi .org/10.1093/ a jen/81.1.79 [PMid:15640464] 
Assessment of Relationship Between Nutritional Status and Handgrip Strength in Hemodialysis

Patients - 9/9

Received: $2020-05-22$

Revised: 2020-08-12

Accepted: 2020-08-13 